\title{
Viktor Orban's Illiberal Democracy in the Indices of the Quality of Democracy
}

\begin{abstract}
The aim of the article is to analyse the assessment of Hungary presented in two democracy's indices: the Freedom in the World Index and the Bertelsmann Stiffung Index in years 2010-2016. The research problem is to identify which of the elements shaping the democracy in Hungary in accordance with the indices have deteriorated. The research is based on the analysis of the content and the existing data. The evaluations of Hungary in the indices of democracy have deteriorated since 2010 when Orban and Fidesz won the parliamentary election and gained power (up to 2016). The changes introduced by Orban in the Constitutional Court and the judiciary, the adoption of a new Basic Law, a new electoral law and the media law cast a shadow over Hungarian democracy. Indices show that the four basic principles of a democratic state have been violated, namely 1) the rule of law, 2) the separation of authorities 3) free and fair elections, and 4) freedom of expression.
\end{abstract}

\section{Keywords:}

Orban, Hungary, illiberal democracy, democracy’s indices, democracy

1 Department of Social Sciences, Department of Finance and Management in Torun, WSB University in Torun, Poland, karolinagawron@wp.pl. 
In fact, since 2010 when Fidesz won the election and quickly introduced reforms, both the journalists and researchers of the topic have begun wondering whether Orban's governance is still democratic. In the newspapers there have been such terms as the "nationalist-tinged, social conservatism", the "illiberal majoritarianism”, "Viktor Orban's personally managed semi-authoritarian order" (Batory, 2015, p. 6), the "managed democracy”, "Führer-democracy”, or "elected despotism” (Kornai, 2015, p. 314). Attila Agh (2016, p. 4) defines the system created by Orban as the defective, Potemkin democracy (2010-2014) as well as the electoral autoracy (from 2014). According to János Kornai (2015, p. 292): "Hungary now belongs to the wide subset of autocratic countries that are "neither democracies nor dictatorships”.

In July 2014 Hungarian Prime Minister Viktor Orban (2014) described the system created by himself as the "illiberal state" claiming that: "The new state that we are constructing in Hungary is an illiberal state, a non-liberal state. The concept of liberal democracy was introduced into the dictionary of political analysis by Fareed Zakaria in 1997. According to the American journalist and political scientist, "democratically elected regimes, often ones that have been reelected or reaffirmed through referenda, are routinely ignoring constitutional limits on their power and depriving their citizens of basic rights and freedoms. (...) we see the rise of a disturbing phenomenon in international life - illiberal democracy" (Zakaria, 1997, p. 22) As Zakaria (2014) noted: "in 1997, I wrote an essay in Foreign Affairs using that same phrase to describe a dangerous trend. (...) But even I never imagined that a national leader - from Europe no less - would use the term as a badge of honor".

The aim of the article is to analyze the assessment of Hungary presented in the indices of democracy developed by Freedom House and Bertelsmann Stiffung in 2010-2016. The chronological framework determines the year 2010 - the election won by Fidesz and taking the power in the country, and 2016 - the available data. The research problem is to identify which of the elements shaping the democracy in Hungary in accordance with the indices have deteriorated. Based on the analysis of the content and the existing data, first the indices of democracy and the evaluation of Hungary within them will be presented and then the elements of Hungary's system that fall in the indices least, thus impinge on the quality of the democracy in Hungary, will be indicated. 


\section{INDICES OF DEMOCRACY AND THE EVALUATION OF HUNGARY IN THEM}

In Bernard Crick’s (2002, p. 1) opinion, democracy is "an essentially contested concept". It should not be surprising, therefore, that political science is not able to offer a common definition of democracy that will be widely accepted empirically. The definition of democracy is, however, essential in defining and working out the quality of democracy. Analyzing the conceptualizations of the quality of democracy, it can be easily noticed that, especially in the case of the indices of the quality of democracy, the starting points are usually minimalist and procedural definitions ${ }^{2}$. Therefore, analyzing the quality of democracy and referring to the ratings of Hungary in this area, one needs to take into account the fact that indices concentrate on the institutional determinants of democracy. Probably the best example illustrating this approach in the study of the quality of democracy is Freedom in the World, created by the non-governmental organization Freedom House and the most frequently cited by researchers. On the other hand, "The Bertelsmann Transformation Index” (BTI) includes not only institutional determinants but also economic ones that may affect the quality of democracy ${ }^{3}$.

\section{INDEKS FREEDOM HOUSE - FREEDOM IN THE WORLD}

The index developed by the organization Freedom House assesses the condition of democracy based on political rights and civil liberties. Freedom House groups its observations into "free", "partly free" and "not free" states, according to whether the average of the Political Rights and Civil Liberties scores lies between 1 and 2.5 ("free”), between 3 and 5.0 ("partly free”) or between 5.5 and 7 ("not free”). Freedom House also differentiates between "electoral democracies" and "liberal democracies” in its reports. Although liberal democracies are characterised by participation, independent decision-making and the ability of the people or their representatives to vote the political leadership in or out of office, their hallmark is extensively developed, untrammelled civil liberties, which electoral democracies lack (Schmidt, 2015).

2 Comparison of some of the indices of quality of democracy can be found in the works (Munck \& Verkuilen, 2002; Szewczak, 2011; Sroka, 2015).

3 To the problem of Hungarian democracy in the indices of quality of democracy refer Beata Pająk-Patkowska and Krzysztof Patkowski (2014, pp. 25-29). 
Table 1. The assessment of Hungary in the Freedom in the World Index in 2010-2016

\begin{tabular}{lccc}
\hline Indeks Freedom House & $\mathbf{2 0 1 0}$ & $\mathbf{2 0 1 4}$ & $\mathbf{2 0 1 6}$ \\
\hline Status & Free & Free & Free \\
\hline $\begin{array}{l}\text { Freedom rating } \\
\text { (1 = best, 7 = worst) }\end{array}$ & 1.0 & 1,5 & 2.0 \\
\hline $\begin{array}{l}\text { Political rights } \\
\text { (1 = best, 7 = worst) }\end{array}$ & 1.0 & 1.0 & 2.0 \\
\hline 1) Electoral proces & & $36 / 40$ & $32 / 40$ \\
\hline 2) Political pluralism and participation & & $12 / 12$ & $9 / 12$ \\
\hline 3) Functioning of Government & 1.0 & $15 / 16$ & $15 / 16$ \\
\hline Civil liberties & & $9 / 12$ & $8 / 12$ \\
(1 = best, 7 = worst) & & $15 / 6$ & 2.0 \\
\hline 4) Freedom of Expression and Belief & & $12 / 12$ & $47 / 60$ \\
\hline 5) Associational and Organizational Rights & & $11 / 16$ & $13 / 16$ \\
\hline 6) Rule of Law & & $14 / 16$ & $13 / 16$ \\
\hline 7) Personal Autonomy and Individual Rights & & \\
\hline
\end{tabular}

Note. Data from Freedom House (2010, 2014, 2016).

It should be noted that in Freedom in the World the overall rating (Freedom rating) for Hungary has been constantly deteriorating since 2010. Civil liberties deteriorated primarily in 2010-2014, which indicates that Fidesz government is moving away from the values of liberal democracy. Moreover, political rights deteriorated in the years 2014-2016, which signals the departure from the principles of electoral democracy.

\section{3. "THE BERTELSMANN TRANSFORMATION INDEX"}

"The Bertelsmann Transformation Index" (BTI) is the global ranking of quality in democracy, a market economy and political leadership in developing and transformation countries. The Bertelsmann Stiftung has presented it every 2 years since 2003 (Møller \& Skaaning, 2011, pp. 19-20). One part of the BTI, in particular, is suitable for the measurement of democracies (and autocracies): the Status Index. It consists of two elements: 1) democracy status; 2) market economy status. The rating of the Status Index is based on a system of points ranging from one (the worst score) to ten (the best score). This index of the status of democracy is based on five components that are measured using data acquired from expert surveys. A country with a democratic status ranking below 4 is categorized as a hard line 
autocracy. A democratic status score between 4 and 5 means that the country is part of the 'moderate autocracy' group. A country is grouped as a 'highly defective democracy' for a score between 5 and 6 . A country is recognized as a 'defective democracy' for a score between 6 and 8 , and a score of 8 and above earns a country the status of a 'democracy in consolidation'.

Table 2. The assessment of Hungary in the Bertelsmann Transformation Index in 2010-2016

\begin{tabular}{|c|c|c|c|}
\hline & 2010 & 2014 & 2016 \\
\hline Status Index & 9.0 & 8.05 & 7.69 \\
\hline $\begin{array}{l}\text { Democracy Status } \\
\text { Scale } 1-10\end{array}$ & $\begin{array}{c}9.25 \\
\text { Democracy in } \\
\text { consolidation }\end{array}$ & $\begin{array}{c}7.95 \\
\text { Defective } \\
\text { democracy }\end{array}$ & $\begin{array}{c}7.60 \\
\text { Defective } \\
\text { democracy }\end{array}$ \\
\hline a) Stateness & 10.0 & 9.5 & 9.5 \\
\hline a. Monopoly of the use of force & 10.0 & 10 & 10 \\
\hline b. State identity & 10.0 & 9 & 9 \\
\hline c. No interference of religious dogmas & 10.0 & 9 & 9 \\
\hline d. Basic administration & 10.0 & 10 & 10 \\
\hline b) Political Participation & 10.0 & 8.8 & 7.5 \\
\hline a. Free and fair elections & 10.0 & 9 & 7 \\
\hline b. Effective power to govern & 10.0 & 10 & 10 \\
\hline c. Association / assembly rights & 10.0 & 9 & 7 \\
\hline d. Freedom of expression & 10.0 & 7 & 6 \\
\hline c) Rule of Law & 9.0 & 7.3 & 6.5 \\
\hline a. Separation of power & 10.0 & 6 & 5 \\
\hline b. Independent judiciary & 9 & 7 & 6 \\
\hline c. Prosecution of office abuse & 8 & 8 & 7 \\
\hline d. Civil rights & 9 & 8 & 8 \\
\hline d) Stability of Democratic Institutions & 8.5 & 7.5 & 7.5 \\
\hline a. Performance of democratic institutions & 8 & 7 & 7 \\
\hline b. Commitment to democratic institutions & 9 & 8 & 8 \\
\hline e) Political and Social Integration & 8.8 & 6.8 & 7 \\
\hline a. Party system & 10 & 7 & 7 \\
\hline b. Interest groups & 8 & 7 & 7 \\
\hline c. Approval of democracy & 9 & 7 & 8 \\
\hline d. Social capital & 8 & 6 & 6 \\
\hline
\end{tabular}




\begin{tabular}{lccc}
\hline & 2010 & 2014 & 2016 \\
\hline $\begin{array}{l}\text { Market Economy Status } \\
\text { - Socioeconomic level }\end{array}$ & 8.75 & $\mathbf{8 . 1 4}$ & 7.79 \\
- Market Organization & & & \\
- Currency and Price Stability & & & \\
- Private Property & & & \\
- Welfare Regime & & & \\
- Economic Performance & & & \\
- Sustainability & & & \\
\hline
\end{tabular}

Note. Data from Bertelsmann Stiftung (2010, 2014, 2016).

It should be noted that in the years 2010-2016 the value of Hungary deteriorated. Most importantly, Hungary declined from the level of a 'democracy in consolidation' to the level of a defective democracy ${ }^{4}$. The deterioration in the Rule of Law criteria, especially in the separation of power and the independent judiciary and the deterioration in the Political Participation criteria, especially a free and fair election, association / assembly rights and freedom of expression, had a significant impact. There was also a decrease in the party system criterion. The indicators related directly to the institution were slightly changed. It should also be noted that the Approval of democracy score increased in 2016, when compared to the one in 2014. This can be explained by the fact that Orban's government is supported by Hungarians ${ }^{5}$.

\section{DETERIORATING ELEMENTS OF THE DEMOCRACY IN HUNGARY}

In April 2010, the right-wing Fidesz - the Hungarian Civic Union, with its actual annex - Christian Democratic People's Party (KDNP) won the election to the unicameral National Assembly, where they received a constitutional majority ${ }^{6}$. In April 2014 Fidesz again repeated the resultt. As Bogdan Góralczyk (2014) aptly remarked: "Orban won with the weakness of the opponents but also with his own

4 The concept of defective democracy see Merkel (2004).

5 From the public opinion research conducted by an independent Social Research Institute TÁRKI (Társadalomkutatási Intézet Zrt.) in October 2016 the coalition Fidesz-KDNP enjoyed the support of 32\% of all the respondents and 54\% among their voters. (TÁRKI, 2016).

6 In October 2010, Fidesz won the victory in the local elections. His candidates for mayors won in 22 of the 23 biggest cities, including Budapest.

7 In addition, in May 2014 he won the elections to the European Parliament and in October he won the local elections. 
activity, resourcefulness and efficiency".

The vision of introducing a new political and economic system appeared in the Programme of National Cooperation (2010), one of the first programs Orban's government adopted shortly after winning the 2010 election and in the Basic Law of Hungry (2011) in 2011 ${ }^{8}$, as well as in individual Orban's statements. The system was to be based on democracy understood as the democratic will of the majority of citizens, whose pillars were work, home, family, health and order, and above all, the Hungarian people. The assumptions of the system are accurately represented in Orban's (2014) words: “Money capitalism replaced by a work-based economy. Fragmentation replaced by citizenship and the unification of the nation. A system of liberal politics replaced by a system of national politics. Reinstating the rights of Christian culture instead of value neutrality. Liberal public morals replaced by the unconditional respect of human dignity”. The basis of the system is to reject liberal thinking which attaches great importance to an entity and its welfare. In the opinion of the leader of Fidesz, liberal thinking was the cause of the financial crisis in 2008. Moreover, it is the cause of the restricting freedom of political correctness and moral relativism. Orban (2016) wants to introduce, as defined by himself, a genuine democracy, which most importantly will respect public good, in which the winning majority will have appropriate tools of governance. Despite the recognition of democracy, the indices of the quality of democracy show that individual elements of the political system in Hungary deteriorated in the years 2010-2016, in particular the following four: 1) the rule of law, 2) the separation of authorities 3) free and fair elections and 4) freedom of expression.

\subsection{THE RULE OF LAW}

Both Freedom House and Bertelsmann Stiftung indicate that the biggest deterioration occurred in the value of Rule of Law. Although various idices apply the area of rule of law to other aspects ${ }^{9}$, both see its essence in the independence of the judici-

8 The Basic Law of Hungary, adopted on 18 April, signed on 25 April 2011 by the Hungarian President Pál Schmitt and published in the Official Gazette entered into force on 1 January 2012, replacing the Constitution of the Republic of Hungary of 1949. A thorough analysis of the Basic Law of Hungary see. Miklós Bánkuti, Gábor Halmai and Kim Lane Scheppele (2012).

9 Freedom House in the area of rule of law includes the following issues and questions: Is there an independent judiciary? Does the rule of law prevail in civil and criminal matters? Are police under direct civilian control? Is there protection from political terror, unjustified imprisonment, exile, or torture, whether by groups that support or oppose the system? Is there freedom from war and insurgencies? Do laws, policies, and practices guarantee equal treatment of various segments of the population? (Freedom House, 2016a). While for Bertelsmann Stiftung; the criteria for rule of 
ary. It seems that the independence of the judiciary in Hungary has deteriorated.

The changes made in the Constitutional Court may be a significant step to reduce the independence of the judiciary. As Zoltán Szente (2014) noted: “In general, it can be said that the institutional balances of the executive power have considerably weakened. Some of them have lost their independence, or some of their control powers. Both relate to the Constitutional Court, which was the most effective and strongest counterbalance of the Executive for two decades”.

The change of the position of the Constitutional Court concerned three aspects: 1) the way in which judges were appointed ${ }^{10}, 2$ ) the court's overall impact and 3) the court's authority (Havlík, 2016, p. 59). The standing and power of the Constitutional Court within the Hungarian political system has been weakened. According to the amendment of the Constitution, the Constitutional Tribunal lost some of their prerogatives. The government proposed that some issues (in particular those that cannot be altered through referenda, such as taxes, pensions or international affairs) will be taken out of the court's jurisdiction, which significantly restricted the authority of the Constitutional Court. The right to rule on the conformity of budgetary laws to the Basic Law has been limited to testing the conformity to some laws included in the Constitution, namely, the right to life and human dignity, the right to protection of personal data, the right to freedom of thought, conscience and religion and to the laws related to Hungarian citizenship. In 2013, Fidesz also introduced the following provisions to the Constitution, namely, that the Constitutional Court cannot rely on the judgements given before the entry of the new Basic Law into force, i.e. before 1 January 2012, and that the Constitutional Court can adjudicate only on procedural matters. In addition, the Basic Law eliminated the principle of actio popularis, which gives every citizen the right to turn to the Constitutional Court with the question of constitutionality (Kovács \& Tóth, 2011). The new constitution introduced the so-called German model of a constitutional complaint based on an alleged violation of basic rights. The Leader of Fidesz applies the practice that, when the Constitutional Court

law indicate the extent to which the state authorities place checks and balances on each other and the extent to which civil rights and liberties are guaranteed. The index assumes four indicators in this area: 1) Separation of power; 2) Independent judiciary; 3) Prosecution of office abuse; 4) Civil rights (Bertelsmann Stiftung, 2016a).

10 The number of judges increased from 11 to 15 and judges' terms of office extended from 9 to 12 years. Although the mode of selection of judges remained by the National Assembly by a majority of $2 / 3$, but there was a modification. The modification of the parliamentary committee for nominating judges to the Constitutional Court. Previously, representatives of all parliamentary fractions were included in the committee. The amendment changed the set-up of the committee to proportionally represent the distribution of power within the Parliament. (Hungarian Helsinki Committee, 2015). 
vetoes controversial government’s decisions, Orbán cancels its verdicts making amendments to the Constitution.

The need for introducing changes by Orban can be explained by Arthur Wołek's (2014) words: "From the body of a clearly political sense, a kind of third legislative chamber he is to become an institution that defends the coherence of the law system of law and the citizens' rights”.

The independence of the judiciary was violated also by Orban's trying to take control over the judiciary. The President of the Supreme Court, who had been appointed before 2010, was unlawful dismissed early, before his mandate expired (The European Court of Human Rights, 2016). The new institution, i.e. the National Office for the Judiciary was appointed. Its chairman is elected for a term of nine years by the $2 / 3$ of the National Assembly. The office has a large power, not only to appoint judges, but also to decide which court will run a case. Later, as a result of protests in Hungary and from abroad, the sphere of authority of the office was reduced, but its influence has remained significant (Kornai, 2015, p. 282). In 2011, the Parliament decided that the judges were to retire not at the age of 62 but at the age of 70. According to Kornai (2015, p. 282) the change of the retirement period is: the result that the older generation was expelled. This affected several judges in leading positions within the judiciary system who had been appointed before the present ruling group came to power, and although this measure was subsequently annulled by the relevant international court, so that the people involved obtained at least moral redress, most of them were not able to return to their previous leading positions.

\subsection{SEPARATION OF POWER}

The new Hungarian Constitution, known as the Basic Law, in accordance with the provisions has not changed the system in Hungary. However, the fact that Fidesz obtained a constitutional majority in the National Assembly twice, in 2010 and $2014^{11}$, actually made the parliament a machine to pass bills prepared by the government. As Scheppele (2013, p. 561) noted: "in their first three years in office, they amended the old constitution 12 times to facilitate the passage of a new constitution. Once they adopted a new constitution, it, too, was amended frequently. They rammed through more than 700 new laws, changing everything from the civil code and the criminal code to laws on the judiciary, the constitutional court, national security, the media, elections, data protection, and more - with the

11 As a result of the elections in February 2015 Fidesz lost the constitutional majority. 
votes of only their own party". As it was indicated earlier, the independence of the judiciary was also violated. Thus, the basis of a democratic system: check and balance between the legislative, the executive and the judicial power was shaken.

In addition Fidesz took control of previously independent institutions, including the Constitutional Court, the Central Bank, and the offices of the Ombudsman and the Public Prosecutor, the presidency, the media council, the state audit office, the fiscal council, the central statistical office, the competition authority (the office in charge of enforcing procompetition laws) (Rupnik, 2012, p. 133). Orban's government has also introduced a number of personnel changes (Magyar, 2016), which included among others, the president's office, the central bank, the general staff, the police and intelligence command, the management of many state-owned enterprises (including the energy group MVM, the post), the diplomatic corps. According to Atilla Agh (2016, p. 5): "The role of government is expanding, and Fidesz needs people to cover the newly colonized social areas, to control everything from economy to civil society".

The phenomenon of disturbing the balance between authorities, as well as taking over the state is a phenomenon that is dangerous to democracy. It supports negative phenomena such as corruption and clientelism. According to Abby Innes (2015, p. 99): "The widespread corruption of previous governments has consequently not been eradicated so much as systematized”. As Kornai (2015, p. 285) adds: "A new term has been introduced into everyday Hungarian: "Fidesz-közeli cég”, meaning “a near-to-Fidesz company”. Such firms do not belong to the party, but the sole or principal owner of the company is a crony of the political center". The problem of corruption in Hungary has been reflected in the country's relations with the European Union and the USA (Jenne and Mudde, p. 149).

\subsection{FREE AND FAIR ELECTIONS}

The free and fair elections value in The Bertelsmann Transformation Index in Freedom House is defined as an electoral process ${ }^{12}$. It is one of the primary elements determining democracy in general: „There may be little consensus in the democracy debate (...) but there is certainly now and international consensus on the building blocks of democracy, and on free and fair and genuine elections as a central feature in the construct” (Goodwin-Gill, 2006, p. 72).

12 Freedom House under the Electoral Process asks the following questions: Is the head of government or other chief national authority elected through free and fair elections? Are the national legislative representatives elected through free and fair elections? (Freedom House, 2016a). 
The adoption of a new electoral law by Fidesz in December 2011 led to the deterioration of free and fair elections score ${ }^{13}$. The most important changes introduced by the new Act:

1) The number of deputies in the unicameral National Assembly decreased from 386 to 199. 106 deputies will be elected in single-seat constituencies and 93 ones from national party lists.

2) The boundaries of constituencies were changed (and defined according to the interest of the ruling).

3) The second round of an election in single-mandate constituencies was dropped. The two-round system was replaced with the first-past-the-post system (Tóka, 2014).

4) The majority component in a mixed electoral system was strengthened. Although the electoral system remained mixed, the proportion of mandates distributed through the majority system increased, which reduced the overall level of proportionality and strengthened Fidesz’s position (Havlík, 2016).

5) Hungarian citizens with dual citizenship living abroad nearby were allowed to vote by correspondence. Hungarian citizens living in Western countries were not allowed to do that.

Another change in the electoral legislation of November 2012 (later annulled by the Constitutional Court) that required compulsory voter registration prior to elections has also proved controversial. In addition, the amendments to the electoral law assume; that the election campaign will be conducted just 50 days before the election; that it will not be able to be kept in private media (including electronic ones), and - on the Internet. The election silence, during which public opinion polls will not be disclosed, will be extended to eight days before the election. The process of registration was made more complicated. The number of required signatures increased, and the minimum number of required candidates in the majority portion of the electoral system (which was a condition for the submission of an electoral list for the proportional portion) has also increased.

The way how the changes of the electoral law introduced by the government of Fidesz in 2011 and 2012 affected the election results are shown in Table 3.

13 The new electoral law was adopted December 23, 2011 year. It introduced a number of modifications beneficial to the strongest party. The new law on the voting procedure was also adopted (Kornai, 2015, pp. 290, 313-314). 
Table 3. Results of parliamentary elections in 2010 and 2014: Share of Fidesz-KDNP supporters and mandates

\begin{tabular}{lccc}
\hline \multirow{2}{*}{$\begin{array}{l}\text { Parliamentary } \\
\text { election }\end{array}$} & \multicolumn{2}{c}{ Fidesz voters } & Fidesz deputies \\
\cline { 2 - 4 } & $\begin{array}{c}\text { As a proportion of all } \\
\text { eligible voters }\end{array}$ & $\begin{array}{c}\text { As a proportion of all } \\
\text { actual voters }\end{array}$ & $\begin{array}{c}\text { As a proportion of all } \\
\text { deputies }\end{array}$ \\
\hline 2010 & $41.5 \%$ & $53.1 \%$ & $68.1 \%$ \\
\hline 2014 & $26.6 \%$ & $44.9 \%$ & $66.8 \%$ \\
\hline
\end{tabular}

Note. Reprinted from Kornai (2015, p. 290).

It can be noticed that much smaller electoral support in 2014 resulted in almost the same number of seats as in 2010. The election was also assessed (with some objections) by the Organisation for Security and Cooperation in Europe (OSCE). The Final report by The OSCE Office for Democratic Institutions and Human Rights (ODIHR) on 6 April 2014 parliamentary elections in Hungary states that the elections were efficiently administered and offered voters a diverse choice, it also says the main governing party enjoyed an undue advantage because of restrictive campaign regulations, biased media coverage, and campaign activities that blurred the separation between political party and the state. The report also pointed out that a number of key amendments negatively affected the electoral process, including the removal of important checks and balances (ODIHR, 2014).

\subsection{FREEDOM OF EXPRESSION}

The freedom of expression value is defined in Freedom in the World through the following question: Are there free and independent media and other forms of cultural expression? In the Bertelsmann Transformation Index, on the other hand, it is defined through the following statement: Freedom of expression is guaranteed against interference or government restrictions. Individuals, groups and the press can fully exercise these rights. In both indices it deteriorated. This is due to the changes in the media law and the reorganization of the control over the media ${ }^{14}$. In 2010 the Hungarian Parliament passed two laws regulating the media sphere: the Media Act (Act on Media Services and Mass Media, hereinafter) restructuring

14 In 2010 the Hungarian Parliament passed two laws regulating the media sphere: the Media Act (Act CLXXXV of 2010 on Media Services and Mass Media), restructuring the media regulatory system, and the Press Act (Act CIV of 2010 on the Freedom of the Press and the Fundamental Rules on Media Content), concerning media content and press regulation. Those laws are often referred to as the "media package". A thorough analysis of changes in media in Hungary see Péter Bajomi-Lázár (2013). 
the media regulatory system, and the Press Act (Act on the Freedom of the Press and the Fundamental Rules on Media Content) concerning media content and press regulation. Those laws are often referred to as the "media package". The new regulations stated new rules related to the content provided for all media platforms, new rules related to the scope of power of the new regulatory authorities on media and new rules related to the penalties and fines for breaking the new laws. The institutional structure of legal framework was changed and, among other things, new centralized regulatory authorities on media were set up, namely, the National Media and Infocommunications Authority (NMHH), which grants, among others, broadcasters frequency and the Media Council, whose members are elected by the parliament and whose head is appointed for a nine-year term by the Prime Minister. The Council may mete out severe punishments for media publications that violate such criteria, which have not been defined precisely, as an insult to public morality or to religious or ethnic minorities, as well as those politically unsustainable. The council also has the right to inspect all documents of the media even before the statement of the offence. At the same time an attorney of the Media Council was appointed. The attorney is entitled to "inspection, verification, manufacturing copies and summaries of all the measures, letters or documents containing information related to media services, publishing newspapers and broadcasting programs, even if they contain a secret protected by the law". In practice, this may mean that journalists will need to disclose their information sources, hitherto protected in Hungary (Freedom House, 2015).

The changes in the media have been criticized by international organizations, mainly the Council of Europe, the European Union, the Organization for Security and Co-operation in Europe (OSCE) ${ }^{15}$. They pointed out the alleged lack of political independence of the Media Council (the regulatory agency), concentration of powers in the hands of the Media Council, unjustifiably high fines for journalists and media outlets, unclear requirements for content regulation, inadequate protection of journalists' sources, and the government's control over the public service media (Venice Commission, 2015). Under the influence of criticism from the European Commission, Hungary have introduced some changes to the law, for example, the non-commercial blogs and web logs were excluded.

15 In particular, in 2011 the Commissioner for Human Rights of the Council of Europe expressed concerns over its effects on media pluralism and free speech. In 2012 the Council of Europe issued an expert opinion where it suggested numerous substantial changes to the "media package". 


\section{CONCLUSION}

Since Orban and Fidesz won the parliamentary election in 2010 and gained power in the country, the evaluations of Hungary in the indices of democracy have deteriorated (up to 2016). Although the Freedom in the World Index it is further treated as free but "designation of Free does not mean that a country or territory enjoys perfect freedom or lacks serious problems, only that it enjoys comparatively more freedom than those rated Partly Free or Not Free” (Freedom House, 2016b). Hungary recorded a larger decline in the Bertelsmann Stiffung Index, where Hungary was assessed as defective democracy. The changes introduced by Orban in the Constitutional Court and the judiciary, the adoption of a new Basic Law, a new electoral law and the media law cast a shadow over Hungarian democracy. Indices show that the four basic principles of a democratic state have been violated, namely 1) the rule of law, 2) the separation of authorities 3) free and fair elections, and 4) freedom of expression. However, as Zakaria (2007, p. 13) stated: "For people in the West, democracy means "liberal democracy": a political system marked not only by free and fair elections but also by the rule of law, a separation of powers, and the protection of basic liberties of speech, assembly, religion, and property. But this bundle of freedoms - what might be termed "constitutional liberalism" has nothing intrinsically to do with democracy and the two have not always gone together, even in the West”.

\section{References:}

Ágh, A. (2016). The Decline of Democracy in East-Central Europe Hungary as the Worst-Case Scenario. Problems of Post-Communism, 63 (5-6), 277-287. DOI: 10.1080/10758216.2015.1113383.

Bajomi-Lázár, P. (2013). The Party Colonisation of the Media. The Case of Hungary. East European Politics and Societies, 27 (1), 67-87. DOI: 10.1177/0888325412465085.

Bánkuti, M., Halmai, G., \& Scheppele, K.L. (2012). Hungary’s Illiberal Turn: Disabling the Constitution. Journal of Democracy, 23 (3), 38-46.

Batory, A. (2015). Populists in government? Hungary's “system of national cooperation”. Democratization, 23 (2), 1-21. DOI: 10.1080/13510347.2015.1076214.

Bertelsmann Stiftung (2010). BTI 2010 - Hungary Country Report. Gütersloh: Bertelsmann Stiftung. Retrieved from https://www.bti-project.org/fileadmin/files/BTI/Downloads/ Reports/2010/pdf/BTI_2010_Hungary.pdf.

Bertelsmann Stiftung (2014). BTI 2014 - Hungary Country Report. Gütersloh: Bertelsmann Stiftung. Retrieved from https://www.bti-project.org/fileadmin/files/BTI/Downloads/ Reports/2014/pdf/BTI_2014_Hungary.pdf.

Bertelsmann Stiftung (2016). BTI 2016 - Hungary Country Report. Gütersloh: Bertelsmann 
Stiftung. Retrieved from https://www.bti-project.org/fileadmin/files/BTI/Downloads/ Reports/2016/pdf/BTI_2016_Hungary.pdf.

Bertelsmann Stiftung (2016a). BTI 2016 - Methodology. Gütersloh: Bertelsmann Stiftung. Retrieved from https://www.bti-project.org/en/index/methodology/.

Crick, B. (2002). Democracy - A Very Short Introduction. Oxford: Oxford University Press. Freedom House (2010). Freedom in the World 2010: Erosion of Freedom Intesndifies.

Retrieved from https://freedomhouse.org/report/freedom-world/freedom-world-2010. Freedom House (2014). Freedom in the World 2014: The Democratic Leadership Gap. Retrieved from https://freedomhouse.org/report/freedom-world/freedom-world-2014. Freedom House (2015). Freedom of the press. Hungary: 5 years decline in Press Freedom. Retrieved from https://freedomhouse.org/report/freedom-press/2015/hungary.

Freedom House (2016). Freedom in the World 2016: Anxious Dictators, Wavering Democracies: Global Freedon under Pressure. Retrieved from https://freedomhouse.org/ sites/default/files/FH_FITW_Report_2016.pdf.

Freedom House (2016a). Methodology: Freedom in the World. Retrieved from https:// freedomhouse.org/report/freedom-world-2016/methodology.

Goodwin-Gill, G.S. (2006). Free and Fair Elections. Geneva: Inter-Parliamentary Union. Góralczyk, B. (2014, April 10). Orbánizacja. Retrieved from http://www.instytutobywatelski.pl/20435/komentarze/orbanizacja.

Havlík, V. (2016). Populism as a threat to liberal democracy in East Central Europe. In J. Holzer \& M. Mares (Eds.), Challenges to Democracies in East Central Europe (pp. 48-70). London, New York: Routledge.

Hungarian Helsinki Committee (2015). Analysis Of The Performance Of Hungary’s “OneParty Elected” Constitutional Court Judges Between 2011 And 2014. Retrieved from http://www.helsinki.hu/en/hungarys-government-has-taken-control-of-the-constitutional-court/.

Innes, A. (2015). Hungary's Illiberal Democracy. Current History, 114 (770), 95-100.

Jenne, E.K., \& Mudde, C. (2012). Hungary’s Illiberal Turn: Can Outsiders Help? Journal of Democracy 23 (3), 147-155.

Kornai, J. (2015). Hungary U-Turn. Society and Economy, 37 (3), 279-329. DOI: 10.1556/204.2015.37.3.1.

Kovács, K., \& Tóth, G. (2011). Hungary's Constitutional Transformation. European Constitutional Law Review, 7 (2), 183-203. DOI: 10.1017/S1574019611200038.

Magyar, B. (2016). Post-Communist Mafia State: The Case of Hungary. Budapest: Central European University Press.

Merkel, W. (2004). Embedded and Defective Democracies. Democratization, 11(1), 33-58. DOI: 10.1080/13510340412331304598.

Møller, J., \& Skaaning, S.E. (2011). Requisites of Democracy. Conceptualization, measurement, and explanation. London, New York: Routledge.

Munck, G., \& Verkuilen, J. (2002). Conceptualizing and Measuring Democracy: Evaluating Alternative Indices. Comparative Political Studies, 35 (1), 5-34.

Orbán, V. (2014, July 26). Prime Minister Viktor Orbán’s Speech at the 25th Bálványos Summer Free University and Student Camp. Tusnádfürdő (Băile Tuşnad), Romania. Retrieved from http://www.kormany.hu/en/the-prime-minister/the-prime-minister-s- 
speeches/prime-minister-viktor-orban-s-speech-at-the-25th-balvanyos-summer-freeuniversity-and-student-camp.

Orbán, V. (2014, June 6). Prime Minister Viktor Orbán’s Speech in Parliament to present his New Cabinet. Budapest. Retrieved from http://www.kormany.hu/en/the-prime-minister/ the-prime-minister-s-speeches/prime-minister-viktor-orban-s-speech-in-parliament-topresent-his-new-cabinet.

Orbán, V. (2016, November 10). Prime Minister Viktor Orbán’s speech at the conference "Reinvigorating Growth, Competitiveness and Investment - The EU from the Baltics, through Central Europe, to the Mediterranean”. Budapest. Retrieved from http:// www.kormany.hu/en/the-prime-minister/the-prime-minister-s-speeches/prime-ministerviktor-orban-s-speech-at-the-conference-reinvigorating-growth-competitiveness-andinvestment-the-eu-from-the-baltics-through-central-europe-to-the-mediterranean.

Pająk-Patkowska, B., \& Patkowski, K. (2014). Węgierska droga do i od demokracji. Przegląd Politologiczny, 2, 25-29.

Rupnik, J. (2012). Hungary's Illiberal Turn: How Things Went Wrong. Journal of Democracy, 23 (3), 132-137.

Scheppele, K.L. (2013). The Rule of Law and Frankenstate: Why Governance Checklists Do Not Work. Governance, 26 (4), 559-562. DOI: 10.1111/gove.12049.

Schmidt, M.G. (2015). Measuring Democracy and Autocracy. Institut für Politische Wissenschaft-Universität Heidelberg.

Sroka, A. (2015). Jakość demokracji - jako nowy obszar badań w naukach politycznych. E-Politicon, XIV, 86-103.

Szente, Z. (2014, June 16-20). Unorthodox Measures in a Partisan Constitution in Hungary - Towards a Nationalist Model of Constitution-making?. Paper presented at IXth World Congress of Constitutional Law, "Constitutional Challenges: Global and Local". Oslo. Retrieved from http://www.jus.uio.no/english/research/news-and-events/events/ conferences/2014/wccl-cmdc/wccl/papers/ws5/w5-szente.pdf.

Szewczak, W. (2011). Jak zmierzyć demokrację? Skale pomiaru demokracji politycznej stosowane w politologii porównawczej. Przegląd Politologiczny, 1, 121-137.

TÁRKI -Társadalomkutatási Intézet Zrt (2016, October 26). Stabil kormánypártok, gyengülő Jobbik. Retrieved from http://www.tarki.hu/hu/news/2016/kitekint/20161026_valasztas.html.

The Basic Law of Hungary (2011, April 25). Retrieved from http:/libr.sejm.gov.pl/tek01/ txt/konst/wegry2011.html\#mozTocId850585.

The European Court of Human Rights (2016, June 23). Grand Chamber Case of Baka v. Hungary. Retrieved from https://www.icj.org/wp-content/uploads/2016/06/HungaryCASE-OF-BAKA-v.-HUNGARY.pdf.

The OSCE Office for Democratic Institutions and Human Rights (ODIHR). (2014, July 11). The Final report on the 6 April 2014 parliamentary elections in Hungary. Retrieved from http://www.osce.org/odihr/elections/hungary/121098.

The Programme of National Cooperation (2010, July 14). Retrieved from http://wwwarchiv.parlament.hu/irom39/00047/00047_e.pdf.

Tóka, G. (2014). Constitutional Principles and Electoral Democracy in Hungary. In E. Bos 
\& K. Pócza (Eds.), Constitution Building in Consolidated Democracies: A New Beginning or Decay of a Political System? (pp. 311-329). Baden-Baden: Nomos Verlag. Venice Commission. European Commission For Democracy Through Law (2015, June 22). Opinion On Media Legislation (Act Clxxxv On Media Services And On The Mass Media, Act Civ On The Freedom Of The Press, And The Legislation On Taxation Of Advertisment Revenues Of Mass Media) of Hungary adopted by the Venice Commission at its 103rd Plenary Session (Venice, 19-20 June 2015). Strasbourg. Opinion no. 798 / 2015. Retrieved from http://www.venice.coe.int/webforms/documents/default. aspx?pdffile=CDL-AD(2015)015-e.

Wołek, A. (2016). Stary ustrój i personalna rewolucja. In L. Skiba, M. Rapkiewicz, \& M. Kędzierski (Eds.), Węgry Orbána - wzór czy przestroga? (pp. 9-16). Warszawa: Instytut Sobieskiego.

Zakaria, F. (1997). The Rise of Illiberal Democracy. Foreign Affairs, 76 (6), 22-43.

Zakaria, F. (2007), The Future of Freedom. Illiberal Democracy at Home and Abroad. London, New York: W.W. Norton \& Company.

Zakaria, F. (2014, July 31). The rise of Putinism. Washington Post. Retrieved from http://www.washingtonpost.com/opinions/fareed-zakaria-the-rise-of-putinism/ 2014/07/31/2c9711d6-18e7-11e4-9e3b-7-f2f110c6265_story.html. 